\title{
Free School Leadership
}

\author{
Meilia Rosani ${ }^{1}$, Misdalina $^{1 *}$, Tri Widayatsih ${ }^{1}$
}

\author{
${ }^{1}$ Universitas PGRI Palembang, Indonesia \\ *Corresponding author. Email: misdalina@univpgri-palembang.ac.id
}

\begin{abstract}
The introduction of free schools needs to be dealt with seriously by the leader. Seriousness is shown by his ability to lead. Leadership is required so that the introduction of free schools can be guided and targets can be accomplished quickly and efficiently. The purpose of this study was to decide how free school leadership is in the Musi Banyuasin Regency (MUBA). This research uses a qualitative approach to the case study process. The data collection technique was conducted by interviewing, analyzing and recording the validity of the data used in the triangulation process. The results show that free school leadership in the MUBA district is focused on coordination, collaboration, productivity in the division of roles, the arrangement of the activities of the management team members in an integrated and sustainable manner between the district management team and the school.
\end{abstract}

Keywords: Leadership, Cohesion, Performance, Sustainability

\section{INTRODUCTION}

The Free School that is introduced in MUBA Regency is a program of the MUBA Regency Government that has been implemented since 2003. Until now, the software has been running well. The success of the program cannot be separated from its leadership and leadership. Leadership is an absolute necessity for a stable organizational life. Leadership is required so that group activities can be guided and goals can be accomplished easily and effectively [1].

Since the leadership of the Regent in the period 2002-2006, free schools have been the solution to the problems that exist in MUBA Regency. Access to education facilities was poor in MUBA Regency that year. Data from the Department of Education and Culture MUBA Regency in 2002 reveals that the number of illiterate people as many as 11,881 and 4500 at school ages 7-12 cannot obtain formal education at school. The standard of human resources is also still poor, as can be seen from the APK for Education in the MUBA district, namely the APK for SD of 118,24 per cent, the APK for SMP of 62,74 per cent and the SMA of 21,83 per cent. This data shows that community involvement in the MUBA district in education is still poor.

Pursuant to Law No 22 of 1999 on the Regional Government Article 13(f) it is specified that the implementation of education and the allocation of human resources are compulsory matters for the
Regional Governments, that education and the enhancement of the quality of human resources in the regions are also the responsibility of the Regional Government. In addition to this clause, the leaders of the MUBA District Government, along with stakeholders (DPRD, relevant agencies, community leaders and NGOs) led by the MUBA Regent at the time, tried to find the best solution to the problem of education. After going through intense phases and meetings, an agreement was eventually reached that an appropriate way to address the issue of low-quality education for the MUBA community was to exclude the cost of 12 years of education, from primary to secondary school levels in the MUBA district. The program will be initiated by the government and all stakeholders beginning in 2003 with the goal of public and private schools.

The MUBA District Government Leaders' initiative to address low access to education earned positive support from different groups, both from stakeholders and from donors. Conceptually, therefore, this initiative is very feasible to execute, the one factor that has a huge effect on the effort to move this initiative is the very high commitment of all stakeholders. Based on the experience of the MUBA Regency Government, good cooperation from all stakeholders is a key factor in the success of this programme. This can be seen from a deep willingness to work together to address the poor standard of human capital in the MUBA culture. This demonstrates the leader's role in the success of free school, through his leadership, so that he can run until now. The role of leaders in organizational management 
is inseparable from how skilled they are in preparing, coordinating, mobilizing/leading and overseeing to ensure that all components of resources work together in an organized manner to properly operate free schools.

Several challenges have been established in the introduction of free schools, including the discipline and efficacy of teaching and learning programs, as well as the concerns of parents of free school students about the quality and quality of education [2], and the quality of education has not improved [3]. In reality, free schools do have to follow the requirements set out in the national education standards in Indonesia, so that the quality of the production produced is in line with the actual educational objectives.

Various issues that need to be addressed in the management of free schools include managementrelated information technology variables that can have an impact and change on leadership habits, sense of duty, decision-making, preparation, workload and teacher performance [4]. The MUBA Regency Free Schools have been running well since 2003 until now. This demonstrates the seriousness of all the parties concerned, by leadership that manages well. According to Ambar, management is a method of using organizational resources to achieve organizational objectives through the planning, organization, management and control functions [5]. Management is the art of completing work by others [6]. In the meantime, according to Arikunto, there are two definitions of services, namely general and unique programmes. In general, a program can be characterized as a schedule or activity design that can be completed in a short time or on a continuous basis by policy. Whereas, in particular, the activity unit, which is the execution of a program, takes place in a continuous phase and takes place in an organisation involving a community of people [7]. In addition, free schooling means that students can go to school without the responsibility of their parents to pay anything and that students receive book loans from the School Library [8]. On the basis of the above belief, leadership in free school management is required by leading other people or groups to achieve organizational objectives, that is to say, free schooling for students without the requirement to pay.

Success in the administration of free schools requires leaders who can transfer organizational members to accomplish objectives such as preparing, organizing, leading, mobilizing, engaging, organising, managing, tracking and reviewing, as well as budgeting that must be enforced in free schools so that they can be properly implemented. Planning is planning tasks over a period of time to accomplish the objectives set [9]. These tasks should be planned to be carried out over a period of time in a systematic, complete calculation and determination of who, where, when and how to achieve the objectives. In addition, organizing in management according to Karnati is any cooperation mechanism run by a group of people to achieve certain objectives [10]. There are three interconnected components, namely a community of individuals, collaboration and certain objectives. Then, according to Wijono, leadership is a leader's attempt to achieve organizational objectives through encouragement, power, inspiration, so that followers are willing to adopt them [11]. In line with Yukl's view, leadership is a process of influencing others to understand and agree on what needs to be achieved and how the work is done effectively, as well as a process of promoting individual and collective efforts to achieve shared goals [12]. Leadership is also, in Nadeak's view, a person's ability to influence others in a community or organization to accept and understand all that needs to be accomplished with predetermined goals [13]. It can therefore be inferred that leadership is a leader who achieves organizational goals by encouragement and facilitation by influencing other people in a group to understand and agree about what needs to be accomplished and how the mission is carried out effectively, whereas supervision is an activity to evaluate, review and match whether the work that has been done is compatible with the planned plans and objectives.

The success of the introduction of free schools in MUBA Regency can be a symbol of successful leadership. The goal of this research is to find out how free school leadership is in MUBA Regency?

\section{METHODS}

This study uses a qualitative approach to the case study process. The goal is to find relevant and unique elements of free school leadership in the MUBA district involved in free schools. Interviews were performed, leadership (a leadership performance and achievement of a free school. Sources of data from representatives of the Education and Culture Office, the Principal, the Students, and the Community. Data collection methods were carried out by interviewing, observing, and recording the quality of the data used in the triangulation process.

\section{RESULTS AND DISCUSSION}

The progress of the MUBA Regency Free Schools cannot be separated from the severity of the parties involved in its implementation. This seriousness can be seen from the leadership of the MUBA Regency local government and related parties in an integrated and sustainable manner in free school management, including the planning, coordination, leadership and supervision that is carried out in an integrated and sustainable manner between the MUBA Regency management team and the school team. Leader's action 
in free school planning is to improve the stability and teamwork of management in planning. Planning for free schools needs to be done in order to fulfill the needs of the school according to the RAPBS and the funds available to the local government of MUBA Regency. Planning for free schooling was introduced by the Regent by instructing him to allocate a budget for the education of all students of the MUBA Regency. Stakeholders endorse this (DPRD, related agencies, NGOs and community leaders). The Education Office, through the MUBA Regency Principal, registers students and sends them to the MUBA District Government to be budgeted for the current year's Budget Activity Plan (RKA).

The leader shall govern the efficient allocation of positions in the planning of free schools. The Planning Sector, in partnership with the School Sector, is active in the preparation of the budget at the Education and Culture Office. Subsequently submitted to the Regional Development Planning Agency of Musi Banyuasin Regency, where the proposal is used as a material for the deliberation process carried out in the Regional Development Plan Deliberation, which is then prepared by the Regency Regional Budget Team, which is directly chaired by the Regional Secretary of Musi Banyuasin Regency, which consists of the Budget Financial Plan. Regions, Regional Infrastructure Planning Department, Regional Revenue Service and Office of the Inspectorate. After the approval of the free school budget proposal by the Regional Apparatus Budget Team, the RKA for Free Schools is sent to the DPRD for discussion in order to gain approval from the DPRD. The Budget Implementation Document (DPA) of the SKPD Office of Education and Culture of Musi Banyuasin Regency will be released upon approval by the DPRD. In accordance with the schedule and criteria set out in the DPA, payment requests may be made by the team according to the schedule and needs. The decision of schools which receive free school funding shall be legalized directly by the Head of Musi Banyuasin Regency Education and Culture Office, and the payment and distribution of free school funds may be made available. In the meantime, school planning starts with the preparation of a budget based on basic student data (DAPODIK). DAPODIK is revised every month by the school operator to make it valid and accountable. If there is a disparity between the DAPODIK and the actual number of students at school later on, the DAPODIK payment would be used. Plans are drawn up with care and tailored to the needs of the school according to the RAPBS.

Leaders must be involved in coordinating free school events. Leaders who run free schools in Musi Banyuasin Regency continue to be governed by regulations that form the legal basis for management. The explanation for this is that the driving force for free schooling is in the possession of the District Education
Office, which serves as an executor in its execution. These Regulations include the Regulation concerning the Organizational Structure, the Definition of Employment and the Role of the Education and Culture Office, the Decree of the Head of the Education and Culture Office concerning the recruitment of Treasurers/PUMC TK/SDN/SMPN/to the Education and Culture Service Unit, the Technical Guidelines for Use and the Obligation Funds for Free School Assistance.

Organizing tasks decided by leadership through the creation of a management team in free schools. The Free School Team included a variety of related components, such as the District Council, the Education and Culture Office, the Classrooms, the Committees and the Community. Continuity between these components in order to work together is an important asset in the success of free schools in MUBA Regency. The smallest agency in the free school system is on the school side as a field implementer. The Principal, by means of a signed decree, authorizes the appropriate officials to carry out free schools properly and in an orderly manner, giving priority to professionalism and accountability.

The management of free schools in MUBA Regency can be seen in the organizational structure of free schools at the service level consisting of the Head of Service, Head of Field, Head of Section as PPTK, and Routine Treasurer as Treasurer of Free Schools. In the meantime, the organizational structure of free schools in schools consists of: principals who collect free school funds, treasurers, and school boards.

The leader should be in a position to increase the quality of the work of the community he leads. The results of the research can be said that the leader can move a free school team to do a good job. This has been shown by the Head of the MUBA Regency Administration, the Head of the Education and Culture Office and the Principal of the PSG in MUBA Regency, who have a high degree of dedication and are synergistic with their respective positions in the success of free schools. Their respective duties shall be as follows: 1) Regent shall specify the Head of the Office as the user of the budget as well as the responsibility for the implementation of the Free School and the Principal for its implementation; 2) the Head of the Office prepares, executes and supervises the introduction of free schools; 3) principals shall enforce and be responsible for the introduction of free schools. The leader in moving to a free school offers mutual confidence and collaboration between members of the management team. This can be seen from the written regular reports issued by each management team on the introduction of free schools.

The leader helps the company with learning and exchanging new ideas. This has taken place in the 
oversight of the introduction of free schools by reports on the utilization of funds. A study on the use of free school funds is made every quarter by the school. Fund management oversight is carried out by the Free School Management Team of the Education and Culture Office, the MUBA Regency Inspectorate and the School Management Team. Routine internal oversight is carried out by the free school management team of the MUBA Regency Education and Culture Office. In the meantime, external supervision is carried out by the MUBA Regency Inspectorate.

Free school leadership is shown from the preparation, demonstrating that the leadership process dynamically affects the members of the management team who appear to be unified and united in seeking the completion of free school planning. This is consistent with Yulk's view that the leader must be able to improve the cohesion of the members of the party, the teamwork and the morale of the members [12][14][15].

Planning for free school starts with the efforts of the leader and the management team to perform outreach to schools, interpersonal contact, and to collect data on students at all levels of school in MUBA Regency. In addition, the data are entered into the budget of the MUBA Regency Education and Culture Office for free schools in accordance with the total sum of each school level in the Budget Activity Plan (RKA). The draft RKA was sent to the MUBA Regency BAPEDDA for use as a material in the development planning deliberation process (MUSRENBANG) and then discussed with the Regency Regional Apparatus Budget Team (TAPD). And after receiving approval from the TPAD, the RKA Free School is sent for approval to the Regency DPRD for discussion at Council level. Following approval, a Budget Implementation Document (DPA) was given to the SKPD of the Education and Culture Office of Musi Banyuasin Regency as the person in charge.

In this report, the authors found that the budgeting of free school activities in the Musi Banyuasin District was focused on the elements defined in the systematic budgeting process. Before the funds were distributed, the educational office in the Musi Banyuasin District took the DAPODIK data for each school, which was first proposed to the Regional Budget Drafting Team for approval by the MUBA Regency DPRD Level II. This shows that the free schools in the MUBA Regency are properly enforced by careful planning processes by the leaders. This is in line with Atmosudirjo's view in Usman that planning is the estimation and determination of everything that will be carried out in order to accomplish those objectives, who does, where, where and how to do it, mistakes in the determination of planning will result in the management of a school that is not working [8]. Leaders include all members of the management team in the planning of free schools, according to Syaddad's report, the planning of which includes the school development team, namely the principal, treasurers, all Waka, selected representatives of teachers and known to the Foundation [16].

Free school leadership in MUBA Regency is demonstrated by organizing it on the basis of the division of tasks and the authority of each. This confirms the findings of Airlanda's research that the effectiveness of the free school policy is also decided by the attitudes and expectations of the school implementers in this case, the city/district education offices and the provincial governments [17]. The organization of free schools in the MUBA district is part of the education and school management team, according to Karnati's opinion that the organization is managed by a group of people working together to achieve those objectives [10]. In carrying out this, any activity that takes place in the school setting needs good organisation so that it can run smoothly. Free School introduced by the Regional Government of Musi Banyuasin Regency as a holistic education concept for all MUBA communities.

In addition, the implementation of free schools is coordinated by senior officials, beginning with the Head of the MUBA Regency Government, the Head of the Education and Culture Office and the School Principal, who have a high degree of engagement and coordination with their respective positions in the implementation of free schools in MUBA Regency. The Regent appoints the Director of the Office as the budget consumer and is also responsible for the implementation of the Free School and the Principal as the budget implementer. The head of the Head of Department, executes and manages the introduction of free schools. Principals implement and are responsible for the introduction of free schools. This shows that they are a leader who can properly handle and run a free school with a high degree of dedication and accountability. In accordance with Wijono's view, leadership is a leader's attempt to achieve organizational goals through encouragement, power, motivation, so that followers are willing to do so [11].

Although supervision by the Head of the Department has been carried out well in accordance with the Regulation of the Regent of Musi Banyuasin concerning the implementation of the supervision of the Free Schools in Musi Banyuasin Regency, the Head of the Office is obliged to supervise the administration of the free school funds in the Education Unit and to supervise the Head of the Office is allowed to do so.

The management of free schools in the MUBA district is in accordance with the jurisdiction of the Education and Culture Office, the MUBA Regency Inspectorate and the School. This supports research [17], which calls for the monitoring role of the 
implementation of the program by the parties concerned, in order to ensure the quality of education.

\section{CONCLUSION}

Free school leadership in the MUBA district in planning demonstrates that the leader is carrying out a complex process by increasing the cohesion of the community members, the cooperation of the members and the determination of the members to achieve the objectives. The management team, with the influence of the leadership, collected data on the number of students through DAPODIK School.

In addition, at the receiving school level for free schools, the principal formed teams consisting of the chairperson and the members, both as the person in charge and as treasurer and data operator, to promote cooperation in the distribution of free school funds. The organization of the establishment of free schools in the district of MUBA is in accordance with its purpose, that is to say, the division of tasks and the division of authority for the team in the district of MUBA Education and Culture and the free school team.

Leadership of free school oversight internally and externally. Free internal control of the schools shall be carried out by the Management Committee of the District Education Office. The MUBA is directly under the supervision of the MUBA Regent and the School Management Team. In the meantime, external oversight includes the MUBA Regency Inspectorate Unit.

\section{AUTHORS' CONTRIBUTION}

Meilia Rosani: designed and performed experiments and analysed data. Misdalina and Tri Widayatsih: Performed analyses and supervised the research and cowrote the paper.

\section{ACKNOWLEDGMENTS}

We would like to express our special thanks and appreciation to the Rector of the University of PGRI, who have assisted us in this wonderful project. This project was funded by a research grant from the University of PGRI. Secondly, we would also like to thank our friends at the University of PGRI who have supported us a great deal in finalizing this project within a short timeframe.

\section{REFERENCES}

[1] Mustafa, Z. \& Maryadi. (2017). Kepemimpinan Pelayan: Dimensi Baru dalam Kepemimpinan [Servant Leadership: A New Dimension in Leadership]. Makasar: Celebes Media Perkasa.
[2] Chu, K. W., Minhong, W., \& Allan, H. Y. (2011). Implementing Knowledge Management in School Environment: Teachers' Perception. International Journal, vol. 3, no. 2.

[3] Afriantoni. (2015). Sekolah Gratis Dan Mutu Sekolah: Studi Kasus Di Sman 2 Babat Toman Musi Banyuasin Sumsel [Free Schools And School Quality: A Case Study At Sman 2 Babat Toman Musi Banyuasin South Sumatra]. Jurnal Dinamika Pendidikan vol. 8, no. 1, pp. 1-10.

[4] Demir, K. (2006). Free School Management Information System in Primary School. The Turkish Online Journal of Educational Technology-TOJET, vol. 5, no. 2.

[5] Ambar, W. S. (2007). Manajemen Sarana Prasarana [Infrastructure Management]. Jakarta: Multi Karya Mulia.

[6] Pananrangi, A. R. (2017). Manajemen Pendidikan [Education Management]. Makasar: Celebes Media Karsa.

[7] Suharsimi, A. (2009). Evaluasi Program Pendidikan, Pedoman Teoritis Praktis Bagi Praktisi Pendidikan [Evaluation of Educational Programs, Practical Theoretical Guidelines for Educational Practitioners]. Jakarta: PT. Bumi Aksara.

[8] Dananjaya, U. (2005). Sekolah Gratis: Esai-esai Pendidikan yang Membebaskan [Free School: Free Educational Essays]. Jakarta: Paramadina.

[9] Usman, H. (2008). Manajemen [Management]. Jakarta: Bumi Aksara.

[10] Karnati, N. (2019). Manajemen Perkantoran; Analisis Teori dan Aplikasi dalam Organisasi Pendidikan [Office management; Analysis of Theory and Application in Educational Organizations]. Aceh: CV. Bunda Ratu.

[11] Wijono, S. (2018). Kepemimpinan dalam perspektif organisasi [Leadership from an organizational perspective]. Jakarta: Prenadamedia Group.

[12] Yukl, G. (2001). Kepemimpinan dalam Organisasi, alih bahasa Budi Suprianto [Leadership in Organizations, translating Budi Suprianto]. Jakarta: PT. Indeks Kelompok Gramedia.

[13] Nadeak, B. (2018). Kepemimpinan \& Perilaku Organisasi Pendidikan di Era 4.0 [Leadership \& Educational Organizational Behavior in Era 4.0]. Jakarta: UKI Press, 2018.

[14] Forsyth, D. R. (2006). Group Dynamics. New York: Cole-Wadsworth. 
[15] McShane \& Glinow. (2008). Organizational Behavior. Chicago: McGraw Hill.

[16] Syaddad, A. (2020). Sistem Manajemen Pembiayaan Sekolah Gratis (Studi Kasus di SMA Selamat Pagi Indonesia Kota Batu) [Free School Financing Management System (Case Study at SMA Selamat Pagi Indonesia Kota Batu)]. SALIMIYA: Jurnal Studi Ilmu Keagamaan Islam, vol. 1, no. 3, pp. 1-17.

[17] Airlanda, G. S. (2016). Analisis Kualitas Pendidikan Ditinjau Dari Penerapan Kebijakan Sekolah Gratis Di SMA Negeri 1 Weru Kabupaten Sukoharjo [Analysis of the Quality of Education in terms of the Implementation of the Free School Policy at Weru Public High School 1, Sukoharjo Regency]. Jurnal Pendidikan Sains, vol. 4, no. 1, pp. 43-50. 